To cite: AC Diala 'A critique of the judicial attitude towards matrimonial property rights under customary law in Nigeria's southern states' (2018) 18 African Human Rights Law Journal 100-122 http://dx.doi.org/10.17159/1996-2096/2018/v18n1a5

\title{
A critique of the judicial attitude towards matrimonial property rights under customary law in Nigeria's southern states
}

\author{
Anthony C Diala
}

URC Fellow, Centre for Comparative Law in Africa; Managing Editor, Journal of Comparative Law in Africa, University of Cape Town, South Africa

\begin{abstract}
Summary
Thus far, recent judgments on women's property rights delivered by the Nigerian Supreme Court have been perceived as a development of customary law. The article argues that these judgments mask the indifferent attitude of apex courts to women's matrimonial property rights under customary law. This indifference is evident from the Supreme Court's failure to address the preservative philosophy of property rights and the unsuitability of this philosophy to contemporary conditions. To bring this failure into critical focus, the article primarily uses case analyses to critique divorce and succession judgments delivered by the Supreme Court and the Court of Appeal. It finds that apex courts prefer the repugnancy test over the Bill of Rights, using a balancing act that shields the customary law of matrimonial property from constitutional scrutiny. Among other measures, the article suggests that customary law should be unequivocally subjected to the Bill of Rights, and legislation should be enacted to regulate customary laws of succession, marriage and divorce.
\end{abstract}

Key words: customary law; matrimonial property rights; Southern Nigeria; Bill of Rights

LLB (Enugu State University) LLM (Human Rights and Democratisation in Africa) (Pretoria) PhD (Cape Town); anthony.diala@uct.ac.za. This article emerged from the author's PhD study supervised by Prof CN Himonga. I acknowledge the financial assistance of the National Research Foundation of South Africa (Grant 64825), the University of Cape Town Research Committee, and the Social Science Research Council Next Generation in Africa (funded by Carnegie Corporation of New York). The usual caveat applies. 


\section{Introduction}

Unlike countries such as South Africa, Ghana, Kenya and Uganda, the co-existence of customary law and state law in Nigeria is not constitutionally defined. ${ }^{1}$ Customary law is neither directly subjected to the Bill of Rights, ${ }^{2}$ nor are its laws of succession, marriage and divorce statutorily regulated. ${ }^{3}$ The only provisions that resemble statutory regulation are court laws, which provide that a custom shall not be 'enforced as law if it is contrary to public policy, or is not in accordance with natural justice, equity and good conscience'. 4 Notably, customary law is non-uniform and largely unwritten, while state law essentially is transplanted English laws and domestic laws that imitate them. This socio-legal situation has two practical effects on judicial attitude to the customary law of matrimonial property.

First, the application of customary law in the courts is broadly determined by choice of law rules. ${ }^{5}$ Thus, where a man dies intestate, his personal customary law regulates the distribution of his estate unless he was married under the Marriage Act or his property was not subject to customary law. ${ }^{6}$ Second, judges have no firm constitutional basis upon which to adjudicate matrimonial property disputes. For example, a divorcing wife has no legal platform to claim matrimonial property under customary law. ${ }^{7}$ Similarly, she is not empowered to claim maintenance rights as these are regarded as unknown to customary law. ${ }^{8}$ Her lack of entitlement to maintenance is traceable to ancient agrarian settings in which she usually returned to her family

1 'Customary law' is used here to denote, in a broad sense, the various forms of norms which a given population uses to conduct its affairs. It is also referred to as 'people's law, folk law, traditional law' and 'indigenous law'. See BW Morse \& GR Woodman (eds) Indigenous law and the state (1988); A Allot \& GR Woodman People's law and state law: The Bellagio Papers (1985); T Elias The nature of African customary law (1955) 55. Note that, generally, Islamic law is not regarded as customary law in Nigeria. See Alkamawa v Bello (1998) 6 SCNJ 127 129; A Oba 'Islamic law as customary law: The changing perspective in Nigeria' (2002) 51 International and Comparative Law Quarterly 817849.

2 Secs 33-44 of the Constitution of the Federal Republic of Nigeria 1999, as amended.

3 A possible exception to statutory regulation is the Limitation of Dowry Law, Eastern Region Law 23 of 1956, which limits the amount of bride wealth.

4 See, eg, sec 16 of the Customary Court Edict of Imo State. See, generally, A Kolajo Customary law in Nigeria through the cases (2000) 13-14.

5 ES Nwauche 'The constitutional challenge of the integration and interaction of customary and the received English common law in Nigeria and Ghana' (2010) 25 Tulane European and Civil Law Forum 37.

6 In Obusez v Obusez (2001) FWLR (Pt 73) 40, Aderemi JCA stated: 'Where however, a person subject to customary law went on to transact a marriage under the Act, this raises a presumption that the distribution of his estate shall be regulated by the Marriage Act. This presumption can be rebutted if the manner of life of the deceased is suggestive that the deceased wanted customary law to apply.'

7 A Osondu Modern Nigerian family law and practice (2012) 100. Judges interviewed affirmed that women may only claim property purchased with their own funds using receipts, or marriage gifts given in their (maiden) names. 
for sustenance. ${ }^{9}$ To compound her weak legal position, judges tend to apply the customary law captured in precedents with little regard to evolutions in the social settings of the precedents. ${ }^{10}$

Despite the constitutional right to equality, therefore, women were not entitled to inherit property because of a porous legal framework and the custom of male primogeniture - that is inheritance through the eldest male child or relative of a deceased person. This was until the Supreme Court invalidated the male primogeniture custom in April 2014 (April judgments). ${ }^{11}$

The April judgments have been hailed as a development of customary law. ${ }^{12}$ However, this article argues that they merely mask the indifferent attitude of apex courts towards women's matrimonial property rights. This indifference is evident from the Supreme Court's failure to address the social context of property rights under customary law. The agrarian societies in which these rights emerged were founded on families living in close-knit units. ${ }^{13}$ This arrangement was mainly for agricultural and defence purposes, given that family wealth was jointly generated. ${ }^{14}$ In this setting, the best interests of the family were paramount. ${ }^{15}$ To perpetuate clan lineage and keep wealth within the family, therefore, heirs inherited not only the property of deceased persons, but also the responsibility to maintain their dependants. Accordingly, the male primogeniture custom was aimed at caring for the family. ${ }^{16}$ However, today it negatively affects women's matrimonial property rights due to its preservative philosophy, the patrilocal nature of customary marriage, ${ }^{17}$ and the influence of socio-economic changes such as urbanisation,

9 While she could return to her father's house in the pre-colonial era, the diminishing concept of extended families today makes this return difficult. See C Ajaero \& P Onokala 'The effects of rural-urban migration on rural communities of South-Eastern Nigeria' (2013) International Journal of Population Research 1.

$10 \mathrm{Eg}$, in April 2013 the Court of Appeal affirmed that under Abagana customary law, women have no right of inheritance in their late father's estate. See Eucharia Nwinyi v Anthony Ikechukwu Okonkwo (2013) LPELR-21216 (CA).

11 Ukeje v Ukeje (2014) 11 NWLR (Pt 1418) 384-414; Onyibor Anekwe v Maria Nweke (2014) All FWLR (Pt 739) 1154.

12 Eg, see N Chinwuba 'Ending inequality in Nigeria: A refreshing approach from the nation's judiciary' (2015) 29 International Journal of Law, Policy and the Family 341; $\mathrm{O}$ Edu 'A critical analysis of the laws of inheritance in the southern states of Nigeria' (2015) 60 Journal of African Law 149.

13 V Uchendu The Igbo of Southeast Nigeria (1965) 22-25; J Barton et al Law in radically different cultures (1983) 41-42.

14 Uchendu (n 13 above) 22.

15 T Nhlapo 'The African family and women's rights: Friends or foes' (1991) Acta Juridica 138141 145-146 (explaining implications of 'the values underlying the African family').

16 N Okoro The customary laws of succession in Eastern Nigeria and the statutory and judicial rules governing their application (1966) 4.

17 This is evident from women joining their husbands' families after their bride wealth has been paid. See JU Ogbu 'African bride wealth and women's status' (1978) 5 American Ethnologist 241. 
acculturation and independent income. ${ }^{18}$ This patriarchy-patrilocal philosophy of matrimonial property rights, evident from the fact that customary marriage transports and subsumes a women's legal identity into that of her husband, has not been analysed by Nigeria's apex courts.

To bring the attitude of these courts into critical focus, the article analysed 30 notable divorce and succession judgments delivered by the Supreme Court and Court of Appeal since self-governance. It supports this analysis with insight gained from discussions with widows, divorcees, judges, traditional leaders, the staff of non-profit organisations, and social welfare officials in South-East Nigeria. ${ }^{19}$ These discussions, which were accompanied by archival searches, were held between June 2014 and January 2015. The article's focus on apex courts is due to the doctrine of judicial precedent. Given that their decisions bind all other courts, the Supreme Court and Court of Appeal, in a sense, are judicial policy makers.

Following this introduction, the second section of the article describes its analytical framework. It first explains the philosophy of women's matrimonial property rights under customary law. Next it discusses the problematic interaction of normative orders in Nigeria's legal framework, highlighting how this interaction fails to deal with women's inability to legally assert matrimonial property rights. Finally, it explains the flexible nature of customary law and the need for judges to avoid a rule-based approach to customary law adjudication. Using case analysis, the third section critiques the Supreme Court and Court of Appeal's attitude to matrimonial property rights, highlighting their preference of the repugnancy test over the Bill of Rights. The fourth section concludes the article and makes remedial recommendations.

\section{Contextual framework}

As a patrilocal society, ${ }^{20}$ customary law in Southern Nigeria limits women's matrimonial property rights far more than in other regions. Several informants interviewed for this study explained the philosophy of matrimonial property rights under customary law with the following story:

In the days when trees were the playgrounds of squirrels, a chief lay dying. He called a meeting of his clan elders and gave them instructions for the disposition of his vast estate. Among other things, he decreed that his only

18 See, generally, P Iroegbu Marrying wealth, marrying poverty: Gender and bride wealth power in an African society: The Igbo of Nigeria (2007).

19 The research area has a population of about 20 million and a generally homogenous demography. It was chosen as customary law in this region highly restricts women's property rights, unlike in Northern and Western Nigeria.

20 M Green Igbo village affairs: Chiefly with reference to the village of Umueke Agbaja (1947) 155165. 
son should choose just one portion out of his numerous lands and livestock, while his head slave should inherit the rest. Wondering why he made such a strange will, the shocked villagers concluded that he hated his son.

Later, the chief died. On the chosen day for sharing his estate, a large crowd gathered. The son, looking depressed, declined to choose anything until the slave had chosen all he wanted. The slave took everything except the ancestral home, which he wisely left for the son. The villagers praised the slave and pitied the son. As they were about to disperse, the son quickly walked up to the slave, threw his arms around his waist and declared, 'Since you are part of my father's properties, I choose you!'

This story sheds light on the philosophy of women's matrimonial property rights under customary law. Here, the son represents men's matrimonial property rights, while the slave represents married women's property rights. In other words, women's matrimonial property rights are subsumed in their husbands' rights. As outlined in the introduction, in the agrarian past family income was produced jointly, thus giving women neither the need nor the opportunity for independent property acquisition. After observing this social setting, colonial courts concluded that women's matrimonial property rights were subsumed in their husbands' rights, thereby producing the official customary law that women may exit marriage only with their clothes and cooking utensils. ${ }^{21}$ Today, not only has independent income largely replaced group production of family wealth, the nature of matrimonial property has changed from functional to include sophisticated gadgets. Unfortunately, judges have not addressed these changes, thereby causing hardship to women in cases of divorce and inheritance. ${ }^{22}$ While in the past agrarian values and the natural pace of socio-economic changes arguably ameliorated the harsh aspects of patriarchy, Nigeria's colonial experience overturned customary law's agrarian setting and introduced new values that eroded communitarian interests. ${ }^{23}$

Regrettably, the post-colonial legal framework fails to recognise that the customary law of matrimonial property is unsuited to contemporary conditions. ${ }^{24}$ As illustrated by paragraph 3 below, women who contributed to their husbands' economic advancement are left with no financial protection after divorce. For example, where a woman contributed to the improvement of a building in a rural area, she may not recover her contributions. ${ }^{25}$ Indeed, the Supreme Court has affirmed that improvements to such property do not divest

21 Duruaku $v$ Duruaku \& Another (unreported) Suit CC/EZ/IK/2D/2004 Judgment of 26 March 2009 2, citing SNC Obi et al The customary law manual (1977).

22 AC Diala 'Judicial recognition of living customary law in the context of matrimonial property rights in South-East Nigeria' unpublished PhD thesis, University of Cape Town, 2016115.

23 See, eg, Agwu v Nezianya (1949) 12 West African Court of Appeal Report 450 (ruling that family property is disposable).

$24 U$ Ewelukwa 'Post-colonialism, gender, customary injustice: Widows in African societies' (2002) 24 Human Rights Quarterly 427-428 446. 
it of its original character of family ownership. ${ }^{26}$ This situation is aggravated by the patriarchal attitude of many judges. ${ }^{27}$ What then is the legal framework in which judges adjudicate matrimonial property disputes?

\subsection{A problematic legal framework}

As stated in the introduction, the interaction of state law and customary law is problematic. ${ }^{28}$ The non-subjection of customary law to the Bill of Rights, and the non-statutory regulation of marriage and succession under customary law inhibit judges from invoking the Bill of Rights. ${ }^{29}$ Given the supremacy of the Constitution, this, arguably, would not have been the case had the Constitution mandated judges to apply and develop customary law. ${ }^{30}$

Other than the Constitution, statutory laws studiously avoid customary law. For example, section 69 of the Matrimonial Causes Act (MCA), the only law providing for financial relief during divorce, excludes marriages 'entered into according to ... customary law'. ${ }^{31}$ This exclusion of customary law marriages from statutory protection ignores the fact that it is the most common form of marriage in Nigeria. ${ }^{32}$ In any case, laws relating to matrimonial property offer scant protection to women. On the one hand, these laws lack provisions for community of property, ${ }^{33}$ unlike the case in England. On the other hand, they have not been reformed to address the doctrine of marital unity which subsumes a woman's legal identity into that of her husband. 34

Furthermore, there is undue deference to customary law in legislation relating to property. For example, most succession laws incorporate the provisions of section 3(1) of the Wills Law of 1958. ${ }^{35}$ This clause excludes statutory law from regulating the distribution or inheritance of land subject to customary law. It thereby restricts testators' rights to dispose of property in rural areas. This undue

25 A Atsenuwa 'Custom and customary law: Nigerian courts and promises for women's rights' in A Obilade (ed) Contemporary issues in the administration of justice: Essays in honour of Justice Atinuke Ige (2001) 344.

26 Rabiu v Absi (1996) 7 NWLR (Pt 462) 505 SC (69-70).

27 In fact, the old judicial opinion was that women were inheritable chattel. See Amusa v Olawumi (2002) 12 NWLR (Pt 780) 30; Akinnubi v Akinnubi (1997) 2 NWLR (Pt 486) 144; Folami $v$ Cole (1990) 2 NWLR (Pt 133) 445; Aileru v Anibi (1952) 20 NLR 45.

28 Nwauche (n 5 above).

29 Judges confirmed this difficulty during the author's fieldwork.

30 Secs 1(1) \& (3) Constitution.

31 The Matrimonial Causes Act, Cap 220, Laws of the Federation of Nigeria 1990; M7, LFN 2004. See Enweozor v Enweozor (2012) LPELR-8544 (CA).

32 IO Agbede 'Recognition of double marriage in Nigerian law' (1968) 17 International and Comparative Law Quarterly 735.

33 A marriage in community of property is one of equal division of property.

34 See, eg, L Holcombe Wives and property: Reform of the Married Women's Property Law in nineteenth-century England (1983).

35 Cap 133, Laws of Western Nigeria 1958. 
deference to customary law is probably due to verbatim reproductions of English law, which sought to avoid open conflict with customary law. ${ }^{36}$ In sum, Nigeria's legal framework fails to deal with the hardships caused by the application of customary law in modern societies. Faced with this situation, judges apply customary law with their understanding of law and its role in society. However, this understanding tends to be positivist which, as argued below, is unsuited to the nature of customary law.

\subsection{Nature of customary law}

The judicial process often involves questions about the nature and sources of the norms that people contest as law. The approach that judges adopt to answer these questions largely depends on their legal background. ${ }^{37}$ In Nigeria, as in many Anglophone post-colonial states, the training of judges is skewed in favour of a positivist English legal tradition, to the detriment of customary law. ${ }^{38}$ It is necessary to briefly explore legal positivism to understand its impact on customary law adjudication.

Up to the mid-twentieth century, the idea that law is the command of a sovereign, which is backed by force, dominated English philosophical views of law. ${ }^{39}$ Although this command theory was later replaced by a focus on the normative character of law and the institutions that apply it, law never lost a rule-based foundation. In essence, legal positivism, or the notion that law should be disassociated from morality and possess some element of a coercive character, survived the decline of the command theory. ${ }^{40}$ Its survival owes much to Hart's Concept of law, which ameliorated positivist extremities by broadly situating law in a social context. ${ }^{41}$ The key aspects of Hart's ideas are his primary and secondary rules, as well as his 'rule of recognition'. As he famously put it, law is 'the union of primary and secondary rules'. ${ }^{42}$ Primary rules are those rules that people owe a duty to obey, while secondary rules are mere social habits, which people may violate without condemnation. Whereas primary rules satisfy the command theory of law as they focus on the

36 Sec 45(1) of the Interpretation Act, Cap 89, Laws of Nigeria and Lagos 1958.

37 J Stewart 'Why I can't teach customary law' in J Eekelaar \& T Nhlapo (eds) The changing family: International perspectives on the family and family law (1998).

38 O Abdulmumini 'Lawyers, legal education and the Shari'a courts in Nigeria' (2004) 36 Journal of Legal Pluralism 114.

39 L Green 'Legal positivism' in EN Zalta (ed) The Stanford encyclopaedia of philosophy (2009) http://plato.stanford.edu/archives/fall2009/entries/legal-positivism/ (accessed 23 June 2016).

40 J Gardner 'Legal positivism: 51/2 myths' (2001) 46 American Journal of Jurisprudence 199. The chief proponents of the command theory include John Austin, Thomas Hobbes and Jeremy Bentham.

41 HLA Hart The concept of law (1994).

42 Hart (n 41 above) 107. 
actions that individuals must or must not take, secondary rules deviate from it because they hint at other sources of law than a sovereign. ${ }^{43}$

Considering that most customs do not owe their legal status to a law-making authority, Hart's work on the interaction of primary and secondary rules is significant for the judicial recognition of customs as law. ${ }^{44}$ When judges - especially Nigerian judges - say that custom is a source of law, they usually mean those customs that they consider compatible with primary rules - that is recognised state (positivist) law. This creates a problem, given that 'law covers a continuum which runs from the clearest form of state law through to the vaguest forms of informal social control'. ${ }^{45}$ In other words, a positivist or rule-based idea of law is incompatible with the nature of customary law, especially in post-colonial countries. ${ }^{46}$

Customary law has long been acknowledged as a flexible normative system. Its flexibility flows from 'interactive social, economic and legal forces', which compel it to adjust to socio-economic changes. ${ }^{47}$ As Moore showed, these forces interact in a social field containing several normative orders, which may be state, semi-state, or non-state law such as customary law. ${ }^{48}$ Their interactions feed into a norm-creation process, during which various customs, norms or rules compete with state law as 'means of coercing or inducing compliance'. ${ }^{49}$ Arguably, the interaction of customary law with state law results in normative adaptations capable of creating new norms. For example, normative adaptations take place when people agree, negotiate, or reject instructions to register lands or limit amounts payable as bride wealth. ${ }^{50}$ Similarly, normative adaptations occur when the state explicitly or tacitly approves curfews imposed by communities in order to curb crime, or abolishes an animal-inclusive tax policy because it offends customary law. In effect, the competitive interaction of norms in social fields leads to normative adaptations and, subsequently, changes in customary law, of which judges are the arbiters. In essence, normative adaptations to socio-economic changes

43 J Hund "Customary law is what people say it is" - HLA Hart's contribution to legal anthropology' (1998) 84 Archives for Philosophy of Law and Social Philosophy 420.

44 Hart (n 41 above) 48 92. This does not mean an endorsement of Hart's confinement of customary law to a 'pre-legal form of government'. See Hart 116.

45 GR Woodman 'Ideological combat and social observation: Recent debate about legal pluralism' (1998) 42 Journal of Legal Pluralism 45.

46 See, generally, D Pimentel 'Legal pluralism in post-colonial Africa: Linking statutory and customary adjudication in Mozambique' (2014) 14 Yale Human Rights and Development Journal 59.

47 C Himonga \& C Bosch 'The application of African customary law under the Constitution of South Africa: Problems solved or just beginning' (2000) 117 South African Law Journal 319.

48 S Moore 'Law and social change: The semi-autonomous social field as an appropriate subject of study' (1973) 7 Law and Society Review 719.

49 S Moore Law as process: An anthropological approach (1978) 56-57. Even within a social field, there may be normative variations (cultural pluralism). See, eg Egharevba $v$ Orunonghae (2001) 11 NWLR (Pt 724) 318 [CA] 337 per Ibiyeye JCA.

50 See, eg, the Limitation of Dowry Law, Eastern Region Law 23 of 1956. 
underlie customary law's flexibility. The problem seems to lie in recognising when these adaptations acquire the character of law.

Hund's distinction between social habits and social rules offers help for this problem. ${ }^{51}$ A social rule has 'internal' and 'external' aspects. The external aspect is phenomena that are easily observable. While not easily observable, the internal aspect refers to conscious attitudes towards acceptable behaviour, which examine human conduct in order to determine whether a sense of obligation is involved. As Hart put it, it is 'a critical reflective attitude to certain patterns of behaviour as a common standard'. ${ }^{52}$ In other words, deviation from a social habit or custom does not need to attract criticism unless there is a sense of obligation attached to the custom. This sense of obligation gives custom the legal character it requires for its judicial recognition. As Fuller argued, an obligation is not incurred in human actions 'simply because a repetitive pattern can be discerned .... Customary law arises out of repetitive actions when and only when such actions are motivated by a sense of obligation. ${ }^{53}$ Thus, where threatened deviations meet with pressure for conformity, and actual deviations are seen as violations of acceptable conduct, the custom in question should be regarded as law. Hund rightly argues that 'it is the existence of this critical reflective attitude which distinguishes custom simpliciter from customary law'.54

In the above sense, the internal aspects of customs serve as guides to the conduct of social life. ${ }^{55}$ This internal aspect is flexible as it is dependent on contemporary social ideas of acceptable conduct. If only the external aspects of customs are observed by scholars or applied by judges, the result is likely to be what scholars refer to as official customary law. ${ }^{56}$

This brand of customary law covers external perceptions of customs, as reflected in court judgments, textbooks, codifications and restatements. It gives an incomplete picture of customary law as it neglects the foundational values that inform customs. ${ }^{57}$ These values, which underpin the internal aspects of customs, are what explain the manners in which members of a social group view their normative behaviour. Their critical reflective attitude to their rules enables them

51 Hund (n 43 above).

52 Hart (n 41 above) 54.

53 L Fuller 'Human interaction and the law' (1969) 14 American Journal of Jurisprudence 16.

54 As above.

55 Hund (n 43 above) 424.

56 TW Bennett 'Re-introducing African customary law to the South African legal system' (2009) 57 American Journal of Comparative Law 3; Himonga \& Bosch (n 47 above); GR Woodman 'Some realism about customary law - The West African experience' (1969) Wisconsin Law Review 128.

57 Stewart and others referred to these values as underlying general principles. See J Stewart 'Why I can't teach customary law' (1997) 14 Zimbabwe Law Review 18; Nhlapo (n 15 above) 138141 145-146; Dengu-Zvobgo et al Inheritance in Zimbabwe: Law, customs and practices (1994) 252254. 
to determine when a custom has outlived its usefulness or when it needs to be modified to suit socio-economic changes. Therefore, it is important for judges to consider not only the external, but also the internal aspects of customary law. If they focus only on the external aspects, they might miss the values that underpin people's adaptation of customs to socio-economic changes, thereby denying women matrimonial property rights. On the other hand, a holistic approach, which includes both the internal and external aspects of customs, will enable judges to interpret customs in ways that reflect the changed social realities surrounding matrimonial property acquisition.

Unfortunately, Nigerian judges often adopt a positivist approach to customary law by assessing it only from an external point of view that is a rule-based system of law. ${ }^{58}$ The problem with this approach is that it could perpetuate distorted versions of customary law. As scholars revealed, colonial judges generally relied on versions given to them by interpreters and community representatives such as chiefs and elders, some of whom had vested interests in the subject matter in question. ${ }^{59}$ These vested interests ranged from property to political power and gender dominance. ${ }^{60}$ Indeed, African customary law became so distorted that it was described as a "construction" of the colonial judiciary in complicity with (African) elders' ${ }^{61}$

The probability of judicial recognition of distorted versions of customary law is heightened by the doctrine of precedent, which stifles the dynamism of customary law. ${ }^{62}$ As a Supreme Court judge observed, 'customary laws were formulated from time immemorial. As our society advances, they are removed from their pristine social ecology. They meet situations which were inconceivable at the time they took root. ${ }^{63}$ The positivist attitude of judges is worsened by the means of proving customary law.

\subsection{Proof of customary law}

The proof of customary law in Nigeria is bedevilled by several challenges. These include the orality of customs; the technical nature of rules of pleadings; the competence of parties' legal representation; and the legal background of judges. For issues of customary law, the Supreme Court and Court of Appeal may only adjudicate appeals

58 See the discussion in sec 3.

59 See, eg, ML Chanock Law, custom and social order: The colonial experience in Malawi and Zambia (1998); ML Chanock 'Neither customary nor legal: African customary law in an era of family law reform' (1989) 3 International Journal of Law and Family 76; F Snyder 'Colonialism and legal form: The creation of "customary law" in Senegal' (1981) 19 Journal of Legal Pluralism 49.

60 As above. See also Okanlawon v Olayanju (unreported) Suit H05189176, Oshogbo High Court, 24 August 1978, per Sijuwade J.

61 W Ncube 'The white paper on marriage and inheritance in Zimbabwe: An exercise in superfluity and mischief' (1993) 5 Legal Forum 12.

62 Agbai v Okogbue (1991) 7 NWLR (Pt 204) 417.

63 Agbai v Okogbue (n 62 above) per Nwokedi JSC. 
arising from the High Court or customary courts of appeal in Nigeria's federating states. Customary courts which have original jurisdiction over customary law are constituted by a panel of three judges. ${ }^{64}$ The panel presidents are legal practitioners, while other members are drawn from elderly, mostly retired senior public officers, who are deemed to be knowledgeable in the customs of their respective communities. Unlike the case in appellate courts, the Evidence Act is not applicable in customary courts. ${ }^{65}$ Section $16(1)$ of this Act states that '[a] custom may be adopted as part of the law governing a particular set of circumstances if it can be judicially noticed or can be proved to exist by evidence'. From this provision, two means of proving customary law in appellate courts are discernible.

The first is by evidence, and the other is by judicial notice. Section $16(1)$ of the Evidence Act and customary court laws place the burden of proving a custom on the person relying on it. ${ }^{66}$ Section 17 states that 'a custom may be judicially noticed when it has been adjudicated upon once by a superior court of record'. Notably, judicial notice inhibits litigants from showing how their way of life adjusts to socioeconomic changes. ${ }^{67}$ It is only through proving customs that their past and present social settings may be properly articulated and their foundational values revealed. For example, on several occasions, the Supreme Court has declared that the denial of widows' rights of succession to their husbands' estates enjoys judicial notice because of its notoriety. 68

However, judicial notice robs widows of at least three things. The first is an opportunity to explain the foundations of the male primogeniture custom and how this custom is accompanied by heirs' duty to support a deceased person's dependants. ${ }^{69}$ The second is an opportunity to explain how acculturation, urbanisation and other socio-economic changes make it difficult for heirs to fulfil this duty of care. In other words, widows lack a platform to explain the disappearance of a correlation between inheritance and heirs' responsibility to care for deceased persons' dependants. ${ }^{70}$ Finally, women are unable to assert the unsuitability of customary law to their contributions to matrimonial property through their independent income. The best means of establishing customary law thus is by placing the burden of proof on the party asserting a custom's continued relevance.

64 The Panel may sit with two members: sec 3 of the Abia State Customary Courts Law 6 of 2011.

65 Evidence Act of 2011, which repealed the Evidence Act Cap E14, LFN 2004.

66 The Supreme Court has affirmed this position in Sokwo v Kpongbo (2008) 34 WRN 8.

67 Olabanji v Omokewu (1992) 7 SCNJ 266281.

68 Nzekwu v Nzekwu (1989) NWLR (Pt 104) 373; Osilaja v Osilaja (1972) 10 SC 126.

69 Okoro (n 16 above).

70 AC Diala 'Reform of the customary law of inheritance in Nigeria: Lessons from South Africa' (2014) 14 African Human Rights Law Journal 637. 
Notably, the main mode of proof in divorce matters is oral evidence, in which a party must demonstrate the existence of a marriage and why the marriage has broken down. Oral evidence could enable a woman to claim matrimonial property or compensation by showing her contributions to its acquisition. It could also enable her to explain the changing nature of property and the influence of socio-economic changes, such as labour migration and independent income on property acquisition. Accordingly, the proof of customs by evidence is preferable to proof by judicial notice. ${ }^{71}$ This background informs the analysis below of the attitude of Supreme Court and Court of Appeal judges towards women's matrimonial property rights under customary law.

\section{Judicial attitude towards matrimonial property rights}

Rather than the Bill of Rights, the thread running through the cases analysed here is the repugnancy test. The original aim of this test was to ensure that customs did not offend English law and its associated Christian notions of morality. ${ }^{72}$ In Eshugbayi Eleko $v$ Officer Administering the Government of Nigeria, ${ }^{73}$ Lord Atkins declared that a barbarous custom is one that is repugnant to natural justice, equity and good conscience. However, the phrase 'natural justice, equity and good conscience' has never been defined, nor have judges attempted to clearly articulate its meaning. ${ }^{74}$ As Elias put it, in 'many of the cases decided on this principle, no consistent principle is discernible and some of the decisions are hard to justify' ${ }^{75}$ This conclusion remains valid today, as the discussion below illustrates.

\subsection{Judicial use of the repugnancy test}

The decision that typifies the attitude of Nigeria's apex courts to matrimonial property is Nezianya $v$ Okagbue. ${ }^{76}$ After the death of her husband, a widow began letting his houses to tenants. Later on, she sold a portion of the land and, with the proceeds, built two huts on another portion of the land. When she wanted to sell more parcels of land, her husband's family objected. She devised the disputed land to her late daughter's child, Mrs Julie Nezianya, who sued the husband's family. Julie sought exclusive possession of the land, claiming that her grandmother had had long, adverse possession of it. The trial court

71 R Nwabueze 'The dynamics and genius of Nigeria's indigenous legal order' (2002) 1 Indigenous Law Journal 173.

72 Nwabueze (n 71 above) 176; Laoye v Oyetunde (1944) AC 170; T Elias Law and social change in Nigeria (1972) 270-271.

73 (1931) AC 662673.

74 A Obilade The Nigerian legal system (1990) 100.

75 T Elias The judicial process in Commonwealth Africa (1977) 53.

76 (1963) 1 ANLR 352. 
held that possession by a widow of her husband's land cannot negate the rights of her husband's family as to enable her acquire an absolute right of possession against the family. Julie appealed to the Supreme Court.

Here, the key question was twofold. The first is the ambit of a widow's right to her late husband's estate under Onitsha customary law. The second is the custom of male primogeniture which gives the first son (Okpala) the right to alienate his late brother's property during his widow's lifetime. In declaring the respondent's alienation of his brother's property as failing the repugnancy test, the Court stated: ${ }^{77}$

The essence of possession of the wife in such a case is that she occupies the property or deals with it as a recognised member of her husband's family and not as a stranger; nor does she need express consent or permission of the family to occupy the property so long as the family make no objection ... The consent, it would appear, may be actual or implied from the circumstances of the case, but she cannot assume ownership of the property or alienate it. She cannot, by the effluxion of time, claim the property as her own. If the family does not give their consent, she cannot, it would appear, deal with the property. She has, however, a right to occupy the building or part of it, but this is subject to good behaviour.

The Supreme Court did not examine the philosophical foundations of the male primogeniture custom. By subjecting a widow's possessory right to good behaviour, it sought a balance between preserving this custom and curbing its hardship on widows. ${ }^{78}$ Twenty-seven years later it clarified this decision in Nzekwu $v$ Nzekwu. ${ }^{79}$

Here, the deceased had died intestate, leaving a wife, Mrs Christina Nzekwu, and two female children. Mrs Nzekwu's in-laws sold the disputed house and the purchaser gave it out to tenants. The Court of Appeal held that a widow without a male child who chooses to retain her husband's name has the right to reside in the matrimonial home even if she is childless. She also has the right to use her matrimonial property as long as her rights do not negate the rights of her late husband's family.

On appeal, the Supreme Court ruled that a widow has the right to reside in the matrimonial home, to be given farm land for cultivation, and to be supported by her husband's family. However, it upheld the lower court's validation of the male primogeniture custom and affirmed that a widow's matrimonial property rights are relative. Delivering a 74-page judgment, Nnamani JSC declared: ${ }^{80}$

The rights of a widow in her husband's property in customary law have been settled. A widow who chooses to remain in the husband's house and in his name is entitled, in her own right and notwithstanding that she has no children to go on occupying the matrimonial home and to be given 
some share of his farmland for her cultivation and generally to maintenance by her husband's family. Should her husband's family fail to maintain her, it seems that she can let part of the house to tenants and use the rent obtained thereby to maintain herself. Her interest in the house and farmland is merely possessory and not proprietary, so that she cannot dispose of it out-and-out.

Nnamani JSC cited with approval the conclusion of the trial judge, Nwokedi J: 81

Subject to good behaviour, plaintiff in this case has the right of possession of her late husband's property and no member of her husband's family has the right to dispose of the property at least whilst she is still alive ... Any Onitsha custom which postulates that the 1 st defendant has the right to alienate, as the Okpala, property of a deceased person in the lifetime of his widow, is in my view a barbarous and uncivilized custom, which, in my view, should be regarded as repugnant to equity and good conscience.

The Nzekwu judgment showed the Supreme Court's unwillingness to directly confront the male primogeniture custom by analysing its foundational value and relevance to contemporary conditions. Aware that invoking the Bill of Rights would imply a striking down of this custom it resorted to the repugnancy test. Notably, Craig JSC and Nnaemeka-Agu JSC dissented in the Nzekwu case on two grounds. First, they held that Mrs Nzekwu had failed to prove that the disputed property was partitioned to her late husband. Second, they held that her conduct, just like Mrs Nezianya's conduct, was a denial of the family's title, which amounted to bad behaviour. Their reasoning ignores the reality that greedy brothers-in-law could appropriate widows' matrimonial properties on the ground that they had abused their possessory rights.

The Supreme Court's balancing act was bound to lead to inconsistencies, given that the primogeniture custom does not manifest only in matrimonial property disputes. This was the case in Ejiamike $v$ Ejiamike. ${ }^{82}$ Here, the plaintiff claimed that the defendants were jointly managing the property of their late father in disregard of his right as the family head (Okpala). Conversely, the defendants claimed that the custom of male primogeniture relied on by the plaintiff was repugnant to natural justice, equity and good conscience. The trial judge rejected this claim, holding that the onus is on the defendants to establish that the custom relied on by the plaintiff failed the repugnancy test. 83

Twenty-two years later an opportunity to correct this decision and strike down the custom of male primogeniture arose in Okonkwo $v$ Okagbue. ${ }^{84}$ Here, Mr Nnayelugo Okonkwo of Ogbotu village died in 1931, survived by five sons, including the plaintiff. He was also survived by two sisters who were the first and second defendants.

81 Record of appeal 65.

82 (1972) ECSNLR 130 (High Court).

83 As above.

84 (1994) 9 NWLR (Pt 368) 301. 
These childless women had separated from their husbands and returned to their family home at Ogbotu. About 30 years after Okonkwo's death the sisters, acting under Onitsha customary law, married the third defendant for their deceased brother with the consent of some family members and village elders. The third defendant gave birth to six sons, all in Okonkwo's name. The plaintiff and his brothers refused to acknowledge these children.

Interestingly, both the High Court and the Court of Appeal upheld the custom of marriage to a deceased person. On appeal, the Supreme Court declared that the disputed custom not only failed the repugnancy test, but it also contradicted public policy. In a remarkable philosophical turn, the Court declared: 85

A conduct that might be acceptable a hundred years ago may be heresy these days and vice versa. The notion of public policy ought to reflect the change. That a local custom is contrary to public policy and repugnant to natural justice, equity and good conscience necessarily involves a value judgment by the court. But this must objectively relate to contemporary mores, aspirations, expectations and sensitivities of the people of this country and to consensus values in the civilised international community ... We are a part of that community and cannot isolate ourselves from its values. Full cognisance ought to be taken of the current social conditions, experiences and perceptions of the people. After all, custom is not static.

The Court's reference to 'contemporary mores, international community' and changing customary law is worth noting, given its reasoning in the Mojekwu case below. ${ }^{86}$

\subsection{Supreme Court's use of the Bill of Rights}

The Supreme Court's use of the Constitution in customary law issues is staggeringly conservative. The Mojekwu case illustrated that prior to April 2014, the Court's deference to the male primogeniture custom was justified on the need to respect the customary law of communities. $^{87}$ The Court did not seem to mind that its attitude infringed the Constitution's anti-discrimination clause. ${ }^{88}$ The appellant, Mr Iwuchukwu, sued Mrs Mgbafor Mojekwu who, following her death, was substituted by her daughter, the respondent. Mr Iwuchukwu claimed right of occupancy over a property at 61 Venn Road, Onitsha. He claimed that under the oli-ekpe (primogeniture) custom of Nnewi, the brother of a man without a male child inherits his estate, even where the deceased had female children. The High Court dismissed his suit. Notably, the parties did not request the invalidation of the oli-ekpe custom, nor did the trial

85 As above.

86 See also Akpalakpa v Igbaibo (1996) 8 NWLR (Pt 468) 553 (CA), which struck down a custom for allegedly militating against the economic, political and social development of a community.

87 Mojekwu $v$ Mojekwu (1997) 7 NWLR (Pt 512) 283. Following the substitution of the deceased respondent on appeal to the Supreme Court, the case became Mojekwu v Iwuchukwu (2004) 11 NWLR (Pt 883) 196.

88 See also Ejiamike v Ejiamike (n 82 above). 
court address it. In dismissing Mr Iwuchukwu's appeal the Court of Appeal, on its own, invalidated the oli-ekpe as repugnant to natural justice, equity and good conscience. ${ }^{89}$

The first issue on appeal in the Supreme Court was the propriety of the Court of Appeal's unsolicited invalidation of the oli-ekpe custom. The Supreme Court held that in the circumstances, the invalidation was wrong. It based this reasoning on the need for judicial declarations to be founded on the claims of the parties. This finding on pleadings, a well-known judicial principle, 90 is significant for women's access to justice. Women who cannot afford lawyers, or whose lawyers are incompetent, are adversely affected by a strict adherence to rules of pleadings. In attempting to avoid the Bill of Rights and subjectively utilise the repugnancy test, the Supreme Court contradicted itself as follows: ${ }^{91}$

A custom cannot be said to be repugnant to natural justice, equity and good conscience just because it is inconsistent with English Law concepts or some principle of individual rights as understood in any other legal system ... Admittedly, there may be no difficulty in reaching a decision in some obviously outrageous or needlessly discriminatory customs. In some other cases, it may not be so easy.

Given the Court's attitude in issues such as in the Mojekwu case it is difficult to imagine a custom more discriminatory than the oli-ekpe. As if its justification for condemning the invalidation of this custom is not unfortunate enough, the Court went on to make the following astonishing statement: ${ }^{92}$

The (lower court) was no doubt concerned about the perceived discrimination directed against women by the said Nnewi oli-ekpe custom and that is quite understandable. But the language used made the pronouncement so general and far-reaching that it seems to cavil at, and is capable of causing strong feelings against all customs which fail to recognise a role for women - for instance, the custom and tradition of some communities which do not permit women to be natural rulers or family heads. The import is that those communities stand to be condemned without a hearing for such fundamental custom and tradition they practise by the system by which they run their native communities. It would appear for these reasons that the underlying crusade in that pronouncement went too far to stir up a real hornet's nest even if it had been made upon an issue joined by the parties, or properly raised and argued.

The Court's reasoning belittled the supremacy of the Constitution, which imposes a duty on the courts to strike down any law that contradicts the Bill of Rights. ${ }^{93}$ This conservative attitude to women's

89 Per Tobi JCA 304-305.

90 Atoyebi v Odudu (1990) 6 NWLR (Pt 157) 384; Ude v Chimbo (1998) 12 NWLR (Pt 577) 169; Oyekanmi v NEPA (2000) 15 NWLR (Pt 690) 414.

91 Mojekwu $v$ Iwuchukwu (2004) per Uwaifo JSC.

92 As above.

93 Secs 1(1) \& (3) Constitution. 
property rights may be contrasted with the attitude of the Court of Appeal.

\subsection{Use of the Bill of Rights by the Court of Appeal}

In Mojekwu v Ejikeme, ${ }^{94}$ Reuben Mojekwu died intestate in 1996 without any surviving male children. However, he had a daughter named Virginia who gave birth to two daughters. In turn, these daughters gave birth to two sons who, with their mother, constituted the appellants. The appellants claimed that Virginia had undergone the Nnewi custom of Nrachi, thereby entitling her to inherit Reuben's property. The Nrachi custom enabled a daughter to remain unmarried in order to raise male children to succeed her father. Any such daughter assumed the position of a man in her father's house, and was entitled to inherit his property. A key issue for the Court's determination was the validity of the Nrachi custom, which indirectly forbids a widow from inheriting her husband's estate. The Court of Appeal held that the custom failed the repugnancy test because children born to a woman who had undergone this ceremony are denied the paternity of their natural father. ${ }^{95}$ Interestingly, the Court also held that the custom offended section 39(2) of the 1979 Constitution, which prohibited discrimination on the grounds of circumstance of birth. Unlike the Supreme Court it did not hesitate to invoke the Constitution. The following cases show its willingness to invoke the Constitution to protect women.

In Asika $v$ Atuaya ${ }^{96}$ the defendant argued that his siblings were only entitled to inherit their husbands' properties, not their father's estate. The trial court found that under Onitsha customary law women, including the female children of a deceased person, could not inherit their father's land. In partly granting the plaintiffs' claims, it found that where the land is situated in an urban area, the testator may devise it by will to his children, irrespective of their gender. The Court of Appeal ruled that the impugned custom was discriminatory and offended sections $42(1)$ and (2) of the Constitution. ${ }^{97}$ As the Court put it, 'customary laws and statutory provisions cannot, in any way, render constitutional provisions nugatory'. ${ }^{98}$

Notably, the Court of Appeal's stance on the male primogeniture custom contradicted the Supreme Court's decision in Mojekwu $v$ Iwuchukwu, which had overruled the Court of Appeal's invalidation of this custom. In fact, it appears that the Court of Appeal tactfully ignores the Supreme Court's ruling in Mojekwu in favour of its own decision. ${ }^{99}$ In the well-known case of Uke $v$ Iro, ${ }^{100}$ it employed the Bill of Rights to rule that any custom that relegates women to second-

94 Mojekwu v Ejikeme (2000) 5 NWLR 402.

95 The Court with approval cited Edet $v$ Essien (1932) 11 NLR 47 (Nig DC).

96 (2008) 17 NWLR (Pt 1117) 484.

97 Asika $v$ Atuaya (n 96 above) 1313-1314.

98 Asika v Atuaya per Olukayode Ariwoola JSC. 
class citizens is unconstitutional. In Ihejiobi $v$ Ihejiobi, ${ }^{101}$ the Court held that the eviction of Mrs Ihejiobi from her matrimonial home 'in a wheelbarrow in the full view of members of the public is totally inconsistent' with her constitutional rights and 'repugnant to natural justice'. ${ }^{102}$ It affirmed the judgment of the High Court, which had restrained the appellants from disturbing Mrs Ihejiobi's use of her matrimonial property. In Ezeibe $v$ Ezeibe, it imported principles of procedural fairness into customary law in order to protect the rights of a divorced woman. ${ }^{103}$

These contrasting judgments of the Supreme Court and the Court of Appeal do not mean that the latter is not sometimes afflicted with the inconsistency and conservatism of the Supreme Court.

\subsection{Attitude of apex courts to divorce}

With respect to the division of matrimonial property upon marriage dissolution, both courts fail to invoke the Bill of Rights to remedy discrimination against women. This was clearly evident in the case of Onwuchekwa. ${ }^{104}$ Here, a woman claimed a share of her matrimonial property on the ground that she had contributed to the purchase of the land on which the disputed building was erected, as well as to the erection of the building. The Court of Appeal held that she must show sufficient proof of direct financial contribution in order to entitle her to a share of the property. Strangely, it affirmed an Isuikwuato custom which holds that a wife and her properties are chattel owned by her husband. ${ }^{105}$ Instead of declaring this custom unconstitutional, the Court of Appeal stated: ${ }^{106}$

The determining factor or factors should not be the English common law but Nigerian law. It is good law that customary law cannot be said to be repugnant to natural justice, equity and good conscience merely because it is inconsistent with or contrary to English law, as the test of the validity of customary law is never English law.

As seen in Okwueze $v$ Okwueze, ${ }^{107}$ a case decided two years before the Onwuchekwa case, the Court of Appeal played the ostrich with respect to the application of English law to customary law. There, the Supreme Court had imported the English practice of denying custody orders for children below the age of $16 .{ }^{108}$

99 Mojekwu v Ejikeme (2000) 5 NWLR 402; Ojukwu v Ojukwu (2000) LPELR-10566 (CA) paras A-D.

100 (2001) 11 NWLR 196.

101 Romanus Ihejiobi v Grace Ihejiobi (2013) LPELR-21957 (CA) 23.

102 Romanus Ihejiobi $v$ Grace Ihejiobi (n 101 above) per Philomena Ekpe paras F-G.

103 Maduike Ezeibe v Adaku Ezeibe (2013) LPELR-21907 (CA).

104 Onwuchekwa v Onwuchekwa and Obuekwe (1991) 5 NWLR (Pt 194) 739.

105 Isuikwuato is in Abia State.

106 Onwuchekwa v Onwuchekwa and Obuekwe (n 104 above).

107 (1989) 3 NWLR 321.

108 Hall v Hall (1945) 62 TLR 151 (CA). 
In Amadi $v$ Nwosu ${ }^{109}$ the Court of Appeal hid behind technicalities to rule that it cannot fairly assess the separate beneficial interests of a couple by reference to their contributions to the purchase of a house. Mrs Amadi had sued the respondent who had purchased the disputed building from her estranged husband. The Supreme Court affirmed the Court of Appeal's finding, holding that Mrs Amadi's evidence that she 'paid for labour and sand when the house was built' was 'evidence on a matter which was not pleaded ... [and] ought to be disregarded'. ${ }^{110}$ The Court affirmed that a woman cannot claim a share in the division of matrimonial property under customary law, nor can she recover contributions to matrimonial property. ${ }^{111}$ This decision demonstrates the unwillingness of the apex courts to acknowledge the unsuitability of the customary law of matrimonial property to modern conditions. The Supreme Court could have invoked the rights to property, equality and even human dignity to invalidate this law. Just as in numerous cases involving the male primogeniture custom, it failed to do this. It was only in April 2014 that it invalidated this custom. This occurred in the April judgments.

\subsection{April judgments}

In Anekwe $v$ Nweke ${ }^{112}$ a widow, Maria Nweke, sought a declaration of entitlement to a statutory right of occupancy of a parcel of land or, alternatively, a share of the proceeds of its sale. She also sought a restraining order against her eviction by the defendants. In sum, she claimed that she had been disinherited by her late husband's family because she had only (six) female children. She contended that the customs of Awka (in Anambra State) allow a woman to inherit the property of her husband whether she has a male child or not. Interestingly, she relied on an arbitration order by the Ozo Awka Society, which appears to indicate that the custom of primogeniture has adapted to allow a widow to inherit her husband's landed property irrespective of her bad behaviour. A member of this society, Ozo Nwogbo Okafor, stated: 'Under Awka custom, if a man dies without a male child, the wife will not be driven away from her husband's compound. ${ }^{\prime 13}$ This testimony was a clever way of saying that a widow's right to her matrimonial property was no longer dependent on her good behaviour. As the Nezianya $v$ Okabgue case showed, a widow who contests land title with her husband's family opens herself up to accusations of bad behaviour and subsequent disinheritance. This is evident in the aspersions that the defendants cast on Maria's character. ${ }^{114}$ Both the High Court and the Court of Appeal upheld Maria's claims.

109 Adaku Amadi v Edward Nwosu (1992) NWLR (Pt 241) 273; (1992) LPELR-442 (SC).

110 Adaku Amadi v Edward Nwosu (n 109 above) per Kutigi, JSC paras 15F-16F.

111 As above.

112 Anekwe v Nweke (n 11 above) 1154.

113 Record of appeal 106-107.

114 Para 16 of the amended statement of defence. 
On further appeal, the Supreme Court noted that the defendants seemed concerned with preserving 'the age-old, male dominated custom and cultural practices of Awka people on inheritance'.115 Reading the lead judgment, Ogunbiyi JSC dismissed the appeal in favour of Maria as follows: ${ }^{116}$

A custom of this nature in the 21 st century societal setting will only tend to depict the absence of the realities of human civilization. It is punitive, uncivilized and only intended to protect the selfish perpetration of male dominance which is aimed at suppressing the right of the womenfolk in the given society. One would expect that the days of such obvious differential discrimination are over. Any culture that disinherits a daughter from her father's estate or wife from her husband's property ... should be punitively and decisively dealt with ... Such a custom, which militates against women, particularly widows who are denied their inheritance ... [is] repugnant to natural justice, equity and good conscience.

Just as in the judgments discussed above, the apex courts failed to analyse how the customary law of succession has departed from its foundational values. Incredibly, the Supreme Court mentioned neither the equality clause nor the right to property, nor even the right to human dignity. In fact, it studiously avoided the Bill of Rights. It was only in the second April judgment, Ukeje $v$ Ukeje, ${ }^{117}$ that it deployed the Constitution against the male primogeniture custom. The Court ruled: 118

The Igbo native law and custom which deprives children born out of wedlock from sharing the benefit of their father's estate is in breach of section 42(1) and (2) of the Constitution, a fundamental rights provision guaranteed to every Nigerian.

However, Ukeje was not a matrimonial property rights dispute. In any case, it merely affirmed a decision of the Court of Appeal, the relevant aspect of which was uncontested on appeal. Indeed, the Supreme Court affirmed it in a nonchalant manner: ${ }^{119}$

Agreeing with the High Court, the Court of Appeal correctly found that the Igbo native law and custom which disentitles a female from inheriting her late father's estate is void as it conflicts with sections 39(1)(a) and (2) of the 1979 Constitution (as amended). This finding was affirmed by the Court of Appeal. There is no appeal on it. The finding remains inviolate.

In affirming the applicability of the Bill of Rights the Supreme Court failed to indicate whether the Ukeje decision could be extrapolated to women's matrimonial property rights. Perhaps it was conscious that such clarification would have overruled its precedents on the subject.

115 Anekwe v Nweke (n 11 above) para 21.

116 Justices Tanko Muhammad, Muhammad Muntaka-Coomasie, Nwali Sylvester Ngwuta and Olukayode Ariwoola supported the lead judgment.

117 Ukeje v Ukeje (2014) 11 NWLR (Pt 1418) 384-414.

118 Ukeje v Ukeje (n 117 above) per Ogunbiyi JSC 33 paras A-G.

119 Ukeje $v$ Ukeje per Olabode Rhodes-Vivour 32-33 paras E-G. 


\subsubsection{A balancing act}

The April decisions are missed opportunities for the Supreme Court to address the question of how some aspects of customary law no longer suit modern conditions. Notably, in the Nweke case it failed to address the unsuitability of the primogeniture custom to women's independent income and contribution to matrimonial property. Such analysis would have provided a platform for invoking the Bill of Rights. ${ }^{120}$ Among other general pronouncements, it merely declared that 'the custom and practices of Awka people upon which the appellants have relied for their counter claim is hereby out rightly condemned in very strong terms'. ${ }^{121}$ The Court also failed to invite amicus curiae evidence from research institutes and non-governmental agencies to shed light on the challenges of applying customary law outside the social settings in which it emerged. To date such bodies have not appeared in any notable customary law litigation.

Given the Supreme Court's jurisprudence on women's property rights, an obvious conclusion presents itself. Aware that invoking the right to non-discrimination or human dignity would imply a striking down of the male primogeniture custom, the Supreme Court routinely used the repugnancy test. This option enabled it to make subjective judgments on a case-by-case basis, in what is obviously a balancing act. Fortunately for women affected by the male primogeniture custom, there was nothing to balance in the Ukeje case as the constitutional legitimacy of children born out of wedlock was not contested on appeal. As for the Nweke case, the Supreme Court merely affirmed precedents it had established in the Nezianya and Nzekwu cases. The only difference is that it quietly abandoned its subjection of widows' possessory rights over matrimonial property to good behaviour.

\section{Conclusion and the way forward}

The April judgments mask the Supreme Court's indifferent attitude to women's matrimonial property rights. While the Nweke case completely failed to mention the Constitution, the Ukeje case arose from a claim of child legitimacy, not matrimonial property. The Court's attitude helps to explain why it has never invoked the Bill of Rights in matrimonial property disputes. It also has yet to acknowledge or probe adaptations occurring in matrimonial property rights and the dissonance between customary law and its foundational values.

Generally, apex judges are unsympathetic to women's matrimonial property rights. $^{122}$ They often insist that women must prove their

120 Anekwe v Nweke (n 11 above) 36-37 paras A-G. For criticism of the judgment, see Diala (n 70 above) 652.

121 Anekwe $v$ Nweke 36. 
monetary contributions to matrimonial property with cogent evidence such as receipts, and in strict accordance with the rules of pleadings. ${ }^{123}$ Moreover, they surreptitiously ignore the philosophy of matrimonial property rights, which is no longer suited to socioeconomic realities of urbanisation, acculturation and women's independent income.

Judges' attitudes to matrimonial property rights are encouraged by Nigeria's legal framework which neither subjects customary law to the Bill of Rights, nor regulates customary laws of succession and marriage. As Ewelukwa remarked, the unregulated 'coexistence of modern, statutory laws with traditional customary laws and practices - has created a complex and confusing legal regime under which women generally are denied adequate legal protection'. ${ }^{124}$ What then is the way forward in this situation?

\subsection{Recommendations}

The article suggests three remedial measures. First, the status and ambit of customary law need to be defined in the Constitution. It goes without saying that the application of customary law should be unequivocally subjected to the Bill of Rights. It is significant that judgments, in general, rarely use the Bill of Rights to evaluate the validity of customs. ${ }^{125}$ Nigeria's failure to subject customary law to the Bill of Rights perhaps explains why judges prefer to use the repugnancy test. Regrettably, they use it without a discernible judicial philosophy, resulting in an insufficient and incoherent protection of women's matrimonial property rights. Pending constitutional reform, judges should read in the rights to equality, property and human dignity into matrimonial property disputes.

Second, the Matrimonial Causes Act should be amended to turn the legal status of couples into community of property and profit and loss. Presently, this Act merely requires the court to compel couples to make 'a settlement of property ... as the court considers just and equitable in the circumstances of the case'. ${ }^{126}$ Although the Matrimonial Causes Act does not apply to customary marriages, the high frequency of double marriage will positively impact on women's matrimonial property rights.

Third, succession, marriage and divorce under customary law need to be statutorily regulated after widespread consultations and

122 On the Supreme Court's attitude, see E Uzodike 'Developments in Nigerian family law: 1991-1997' in A Bainham (ed) The international survey of family law 1997 (1999) 325-344, who noted the Court's 'cold feet' over discriminatory customs against women.

123 Indeed, judges routinely state that they are not 'Father Christmas'. Eg, see Ugo $v$ Obiekwe (1989) NWLR (Pt 99) 566 31-32; Ekpenyong v Nyong (1975) 2 SC 7180.

124 Ewelukwa (n 24 above).

125 The few exceptions are when the claims of the litigants involve the Bill of Rights, eg Ezeibe v Ezeibe; Ihejiobi v Ihejiobi and Uke v Iro.

$126 \mathrm{Sec}$ 72(1) Matrimonial Causes Act. 
awareness campaigns. Furthermore, section 17 of the Evidence Act should be amended to remove the requirement of judicial notice of customs based on a single decision of a superior court. As argued in paragraph 3 above, judicial notice is incompatible with customary law's flexibility. Because of judicial notice it took the Supreme Court 51 years to overturn Nezianya $v$ Okagbue and stop subjecting widows' matrimonial property rights to good behaviour.

Ultimately, judges should avoid an overly rule-based approach to customary law, as evident in the heavy reliance on precedents. Such reliance undermines customary law's flexibility, which thrives on people's adaptation to socio-economic changes. 